\title{
E-books for Young Readers: A Historical Overview of Interdisciplinary Literatures ${ }^{\mathrm{I}}$
}

\author{
Jennifer Burek Pierce*
}

\section{Introduction}

Even a glance at recent publications about books and reading suggests that digital media are changing book publishing, daily and dramatically. ${ }^{2}$ While sources like John B. Thompson's Merchants of Culture and the recently revamped New York Times best-seller lists testify to the growth and increasing adoption of e-books, ambiguities about the effects of e-books on everything from reading habits to culture to industry are unresolved. A zoro review of Ted Striphas's The Late Age of Print, in which the reviewer twits the book's author with the rhetorical question, "late' as in 'the late John Lennon?' or 'late' as in 'the final period of?," evokes the tensions that arise from the possibility that electronic texts might displace print. ${ }^{3}$ The dynamic further manifests itself in news articles that suggest that burgeoning e-book sales threaten the traditional printed book and in plans by presses that envision a fully electronic future, such as the recently announced restructuring of the University of Missouri Press as a

I The author wishes to acknowledge the support of the American Antiquarian Society, through its Jay and Deborah Last Fellowship, for some of the research behind this essay, and the efforts of Beth Kamp in preparing this manuscript.

* Jennifer Burek Pierce is an associate professor in the School of Library \& Information Science at the University of Iowa. She has held research fellowships at the Center for Historic American Visual Culture at the American Antiquarian Society and at the Winterthur Museum, Library, and Gardens. Her most recent book is What Adolescents Ought to Know: Sexual Health Texts in Early TwentiethCentury America (University of Massachusetts Press, 20II).

2 See, for example, Denise E. Agosto, "More Than Just Books: Children's Literacy in Today's Digital Information World," Children \& Libraries ıo, no. 3 (20I2): 36-40; Hayley Elece McEwing, "Play to Learn: Free Tablet Apps and Recommended Toys for Ages 3-7," Children \& Libraries Io, no. 3 (2012): 45-5I; and Kathryn Zickuhr et al., Libraries, Patrons, and E-Books, Pew Internet \& American Life Project, 22 June 20I2, http://libraries.pewinternet.org/20I2/06/22/ libraries-patrons-and-e-books/.

3 James Lichtenberg, review of The Late Age of Print by Ted Striphas, Publishing Research Quarterly 26, no. I (2010): 76. 
digital-only outlet. ${ }^{4}$ These announcements are, in turn, countered by essays and white papers that reaffirm the vitality of print and the difficulties that remain with e-books. ${ }^{5}$

Although some scholarly assessments of publishing trends contend that we are now experiencing a "heterogeneous, hyper-abundant contemporary book environment" resulting from the blend of old and new publishing models, others predict that e-books will vanquish print. ${ }^{6}$ Neither partisan contextualizes its arguments with reference to the turn of the twenty-first century, when Nuvo Media sold the Rocket eBook and SoftBook Press had its own eponymous device, a time now remembered primarily in talks and opinion pieces like "The Future of Publishing: Why eBooks Failed in 2000 and What That Means for 20I0."7 This not-too-distant episode goes unremarked, and the preponderance of opinion indicates that this time, e-books, with content for all readers, are here to stay. ${ }^{8}$

Evidence of the deterministic popularity of e-books is typically tied to sales figures. The first such reporting came in December 2009 when Business Week reported that Amazon.com sold more e-books than print books for the first time ever during that year's Christmas sales period. ${ }^{9}$ Otherwise, dates in the history of the electronic book are

4 University of Missouri News Bureau, "University of Missouri Announces Innovative Scholarly Communication Initiative," news release, I6 July 20I2, http://munews.missouri.edu/news-releases/2012/o716-university-of-missouriannounces-innovative-scholarly-communication-initiative/.

5 Jennifer Burek Pierce, "Charmed by Books," The Chronicle of Higher Education, I January 20I2; Benton Foundation, "The E-Reader Revolution: Over Just as It Has Begun?” 9 January 2013, http://benton.org/node/142404.

6 Jana Bradley, Bruce Fulton, Marlene Helm, and Katherine A. Pittner, "Nontraditional Book Publishing," First Monday I6, no. 8 (20II), http://firstmonday. $\mathrm{org} / \mathrm{htbin/cgiwrap/bin/ojs/index.php/fm/rt/printerFriendly/3353/3030 \# p6;} \mathrm{Ted}$ Striphas, The Late Age of Print: Everyday Book Culture from Consumerism to Control (New York: Columbia University Press, 20II); Henry Jenkins. Convergence Culture: Where Old and New Media Collide (New York: New York University Press, 2006).

7 Michael Mace, "The Future of Publishing: Why eBooks Failed in 2000 and What That Means for 20Io," Mobile Opportunity (blog), I7 March 20Io, http:// mobileopportunity.blogspot.com/2010/03/future-of-publishing-why-ebooksfailed.html.

8 The development of media for infants is discussed in Ellen Wartella and Michael Robb, "Historical and Recurring Media Concerns," in The Handbook of Children, Media, and Development, ed. Sandra L. Calvert and Barbara J. Wilson (Oxford: Blackwell Publishing Ltd, 2009).

9 Spencer E. Ante, “e-books: Averting a Digital Horror Story," Business Week, 30 December 2009, http://www.businessweek.com/magazine/content/IO_O2/ b4162050103172.htm. 
disputed, perhaps in part because scholars, including book historians, are still making sense of them. ${ }^{10}$ There were attempts to create e-books prior to the establishment of the non-profit organization Project Gutenberg in 1971, but most studies trace the rise of the electronic book to the turn of the twenty-first century, which saw predictions "that e-books would quickly become a substantial and growing part of the market." II In 2012 reports from the Pew Research Center and the New York Times concluded that the availability of new devices in 2006 and 2007 had fueled the increase in the e-book's popularity. ${ }^{\mathrm{I}}$

Nonetheless, the New York Times itself did not embrace the e-book format and only announced reconfigured best-seller lists accounting for electronic fiction and non-fiction titles and combined print and electronic book sales for adult readers in February 20II. ${ }^{\mathrm{I}}$ The newspaper was even more reticent when it came to e-books for children, publishing its first reviews of the app-as-children's-book in late August 2012. ${ }^{14}$ It was not until January 2013 that the New York Times evaluated the sales of e-books for adolescents, assuring readers, "The picture book category will continue to showcase bestselling hardcover picture books - works of art and illustration that can withstand night after night of bedtime reading. We believe these changes represent the best traditions in the way children read as well as the future of young people's literature." ${ }^{\text {Is }}$ The proliferation of digital content has encouraged public libraries, with their significant bookbuying power and their mission to serve a diverse public, regardless of age, to acquire and provide access to e-books. ${ }^{16}$ Prominent library

Io For a brief overview of the contending definitions of e-book, see Laura Manley and Robert P. Holley, "History of the Ebook: The Changing Face of Books," Technical Services Quarterly 29, no. 4 (2012): 293.

II “Obituary for Michael Stern Hart," Project Gutenburg, http://www.gutenberg. org/wiki/Michael_S._Hart; John B. Thompson, Merchants of Culture (Cambridge: Polity Press), 3I4.

I2 David Streitfeld, "The Best Book Reviews Money Can Buy," Business Day, New York Times, 25 August 2012; Zickuhr et al., II.

I3 "Introducing E-Book Best Sellers," Arts Beat/Culture at Large (blog), New York Times, II February 20II, http://artsbeat.blogs.nytimes.com/201I/O2/II/ introducing-e-book-best-sellers/.

I4 J.D. Beiersdorfer, "A World at Your Fingertips," Sunday Book Review, New York Times, 23 August 20I2; Nathan Heller, "Hanging on Every Word: The Fantastic Flying Books of Mr. Morris Lessmore," Sunday Book Review, New York Times, 23 August 2012.

Is "Up Front," Sunday Book Review, New York Times, I6 December 2012.

i6 E-book access certainly may occur outside the institutional environment. Where Robert Darton once articulated a reasonably controlled and orderly progression 
directors, among them Jamie LaRue of Douglas County Libraries in Colorado, have begun to examine their service models in light of the public's increased interest in e-books, characterizing the digital delivery of content as a factor that must change the way libraries operate. ${ }^{17}$ In 2012 it was estimated that three-quarters of American public libraries offer e-book borrowing services to their patrons, and library circulation figures for e-books available from a single vendor reached thirty-five million in $201{ }^{\mathrm{I}}{ }^{8}$ At present, titles for children and teens make up a small proportion of that vendor's offerings. Since, at least anecdotally, American public library directors indicate that children's books make up between one quarter and one third of any given library's circulation, new service directions like the lending of e-books invite questions about how children's media, particularly picture books, will feature in the library of the future. These facts and figures represent serious efforts to anticipate demand and to survive in a changing environment, but a recent study of libraries and e-books, not unlike the New York Times, focused on adults as readers of electronic texts. ${ }^{19}$

What is missing in most assessments of digital publishing and related consumption models, then, is serious or sustained consideration of children's books and how the characteristic elements of children's literature function as digital media. This lacuna in the trade and scholarly literature is notable for many reasons, including the potential market impact of the developing list of children's e-books. Admittedly, Michael S. Hart, founder of Project Gutenberg, saw the electronic book as a free, rather than for-fee, commodity, and there are other online collections of resources for children, like the University of Maryland's International Children's Digital Library,

from author to publisher, to a multi-stage distribution process, digital publishing means an e-book may go directly from author to reader. Robert Darnton, "What Is the History of Books?" Daedalus III, no. 3 (I982): 65-83.

I7 "DCL and Gale Partner for eContent," news release, accessed 3I May 2013, http://douglascountylibraries.org/ content/dcl-and-gale-partner-econtent; James LaRue, “The Last One Standing," Public Libraries Online 5I, no. I (2OI2), http:// www.publiclibrariesonline.org/magazines/featured-articles/last-one-standing; Pat Losinski, "Ebook Strategy and Public Libraries: Slow Just Won't Work Anymore," The Digital Shift (blog), Library Journal Online, 9 July 20I2, http:// www.thedigitalshift.com/20I2/o7/ebooks/ebook-strategy-and-public-librariesslow-just-wont-work-anymore/.

I8 Zickuhr et al., 5, II.

I9 Ibid. 
that operate on the same principle. ${ }^{20}$ Despite Hart's proclamation that "eBooks are the very first thing that we're all able to have as much as we want other than air," the resource he conceptualized as an unfettered adjunct to self-education now has significant commercial potential. ${ }^{2 \mathrm{I}}$ This is especially true of media for young people. In 2008, Seth Lerer observed, "Children's books are now the most profitable area of publishing, and links between traditional and innovative media establish younger readers as the prime market for imaginative writing ... The history of reading perennially links together commerce and interpretation." ${ }^{\prime 2}$ Five years later, however, scrutiny of the youthoriented marketplace suggests that children's literature remains, at root, a print endeavour.

Children's literature, epitomized by the full-colour illustrated picture book, simply does not emulate the trends in publishing for older readers. While there is evidence of increasing amounts of electronic material for children, a host of factors complicates the electronic distribution of children's books. Neither specialists in children's literature nor the champions of the new technologies and formats have convincingly explained why children's books, particularly picture books, linger in what some regard as the quaintly cumbersome world of print.

The continued dominance of print in children's publishing invites several questions, starting with some fairly elementary ones: what is a children's e-book? What kinds of books are available electronically for children? When did the production, sale, and lending of children's e-books begin? How does the illustrative content, so central to many children's books, factor into e-books? Where are these materials made available, and to whom? Do libraries, which have traditionally accounted for a high percentage of book sales, circulate e-books to young patrons? What factors might impede either publication of or access to children's e-books? Finally, while prominent awards such as the Caldecott and the Newbery, and long-standing publications like The Hornbook and entities like the Junior Library Guild, guide parents and librarians with authoritative recommendations about the quality and the appeal of children's books, who functions as tastemaker for electronically published children's books? To understand children's

20 Project Gutenberg, "Obituary for Michael Stern Hart," last modified 29 January 20I3, http://www.gutenberg.org/wiki/Michael_S._Hart.

2I Ibid.

22 Seth Lerer, Children's Literature: A Reader's History from Aesop to Harry Potter (Chicago: University of Chicago Press, 2008), 2. 
books in relation to the larger publishing industry and the broad patterns of its much-touted digital revolution involves analysis of both extant e-books for children and the associated trade and professional literature.

These questions, informed by newer media theories with a bearing on the history of the book, including Henry Jenkins's and Ted Striphas's theories of the relationships between print text and electronic media, suggest why the seemingly simple notion of an e-book for a child might in fact be rather complex. ${ }^{23}$ Moreover, recent commentary by professionals interested in e-book use in classrooms and libraries indicates not only that children's e-books present different publishing problems than e-books for older readers, but also that their reception and their use are complicated by the challenges that device compatibility and digital rights management present. ${ }^{24}$ A $201 \mathrm{I}$ article in School Library Journal summarized these difficulties by noting, "Until recently, ebooks for young children haven't been part of the hyped vernacular of 'game-changing' technology. Instead, ebook conversations have focused on textbooks for older students or text-heavy, adult-oriented titles downloaded to ereaders like the Kindle, Nook, and Sony e-Reader." ${ }^{25}$ Children's e-books, in other words, do not readily resemble the devices and the products that have come to be understood as e-books. As a result, individuals with expertise in the field of children's literature, including librarians, teachers, and scholars in book history, communications, and library and information science, have come to few conclusions about the impact of electronic publishing on children's books.

\section{Children's Literature, Picture Books, and E-books for Children: Initial Definitions}

While outlets like the New York Times seem to regard the e-book for adults as a self-evident, unproblematic category, an overview

23 See Striphas, Late Age of Print; and Jenkins, Convergence Culture.

24 One overview of digital rights management issues involved in e-books, particularly in a library environment, that is frequently discussed is Sarah Houghton, "I Am a Frustrated Ebook (Non)User," Librarian in Black (blog), I4 June 20Io, http://librarianinblack.net/librarianinblack/20Io/o6/ebooks-2.html. Related concerns are discussed in Zickuhr et al.

25 Lisa Guernsey, "Are Ebooks Any Good?" School Library Journal 57, no. 6 (20II): 30. 
of the literature on children's e-books reveals a number of critical ambiguities. ${ }^{26}$ Fundamentally, e-books are texts that are accessed digitally rather than in print. Nonetheless, scholars like Alan Galey see any e-book as a richly ambiguous text. Galey cautions that the term e-book "implies a unity that does not exist," yet the market suggests that the e-book for adult readers is, at any rate, somewhat more readily apprehended than one for children. ${ }^{27}$ Galey's scholarship, in which he states that "digital objects do not speak for themselves," is part of a small corpus giving attention to the performative or interactive features of e-books for adults, and in doing so, helping to create a space for discussing the differences between digital texts for readers of different ages. ${ }^{28}$

In contrast to the text-oriented titles for adults, many e-books for children, particularly those developed in the twenty-first century, have multi-media features such as audio recordings and interactive elements. For example, the much-heralded Alice for the iPad, 3.OI, released in 2010 allows a reader to scatter the sweets that Alice gives as prizes in the caucus race and watch Bill the Lizard fly out of the chimney at the touch of the screen. ${ }^{29}$ The interactive characteristics of children's e-books overlap with other media, such as audiobooks and video games. Since children's e-books may incorporate anything from simple text files to movie-like segments, a survey of the ways the children's e-book has been defined is integral to an analysis of its publishing history.

In addition to complexities of form, children's e-books must be understood, at present, in relation to their print counterparts. Striphas has argued that newer technologies create new ways of responding to print works like the Harry Potter series, and it does not seem coincidental that a primary example of intermediation comes from

26 For all the dramatic pronouncements about what digital publishing means for the future of the book, questions about the boundary between books and other technologies remain.

27 Alan Galey, "The Enkindling Reciter: E-Books in the Bibliographic Imagination," Book History I5 (2012): 213.

28 Galey, 240; other examples include Matthew G. Kirschenbaum, "Track Changes," Matthew B. Kirschenbaum (blog), Io April 20II, http://mkirschenbaum. wordpress.com/20II/o4/ro/track-changes/; and Brian A. Ragen, "Reading Becomes Electric: The Amazon Kindle," Papers on Language and Literature 44, no. 3 (2008): 328-32.

29 Lewis Carroll, Alice for the iPad, 3.0I (Atomic Antelope, 20I0), promotional copy http://www.atomicantelope.com/alice/. 
the vast stores of children's literature. ${ }^{30}$ The vast majority of children's e-books are derived from print books, whether a classic like Lewis Carroll's Alice's Adventures in Wonderland or the more recent Don't Let the Pigeon Run This App, based on the Mo Willems' title, Don't Let the Pigeon Drive the Bus. Relatively few fit the rubric of "born-digital" projects. ${ }^{3 \mathrm{I}}$ It should be acknowledged that the connection between print book and mobile device or reader app has many variants, a recent example being the Imag.N.O.Tron iPad app that, used in conjunction with the print edition of The Fantastic Flying Books of Mr. Morris Lessmore by William Joyce and Joe Bluhm, reads the story aloud while creating a three dimensional rendition of the story that transposes images onto the reader's environment. ${ }^{32}$ The relationship between print and e-books for children is further complicated by the fact that no major children's literature award has either recognized the e-book as a category or made a commendation based solely on an electronic text. At the time of writing, the development of awards for e-books seems to be the effort of commercial groups, whether singly or collectively. ${ }^{33}$

Most major review sources have made only preliminary moves toward assessing children's e-books. These commentaries typically appear as special features in professional or academic periodicals rather

30 Striphas, The Late Age of Print, $\mathrm{I} 4 \mathrm{I}-74$.

31 The print origins of most children's e-books distinguish them from best-selling e-books for adults, some of which achieved high sales rankings before printed versions of the titles were available. A key instance of the phenomenon of digitally driven sales is the Fifty Shades of Grey trilogy, of which a quarter-million copies were sold electronically in the U.S. by March 20I2. For details, see Julie Bosman, "Discreetly Digital, Erotic Novel Sets American Women Abuzz," Business Day / Media \& Advertising, The New York Times, 9 March 20I2, http://www.nytimes. $\mathrm{com} / 20 \mathrm{I} 2 / 03 / \mathrm{Io} / \mathrm{business} / \mathrm{media} / \mathrm{an}$-erotic-novel-50-shades-of-grey-goes-viralwith-women.html?_r=I\&pagewanted=all.

32 Daryl Grabarek, "Bill Joyce and Brandon Oldenburg Bend Reality," Touch and Go (blog), School Library Journal, I3 August 2012, http://blog. schoollibraryjournal.com/touchandgo?utm_source=hbook\&utm_medium= web\&utm_campaign=touchandgo.

33 Apple has been identified as a solo award producer while Global Ebook Awards is an entity whose sponsors and affiliates are several major media corporations. A blog post by one former Global Ebook Awards judge indicates that entry fees are required, that proprietary technologies interfere with access to submissions, and that he has parted ways with the organization; see Ted Summerfield, "I've Resigned as a 2012 Global Ebooks Awards Judge," Ebooks by Ted Summerfield (blog), 6 March 20I2, http://punzhupuzzles.wordpress.com/2012/03/o6/iveresigned-as-20I2-global-ebook-awards-judge/. For the primary Global Ebook Awards page see http://globalebookawards.com/. 
than as established, recurring recommendations. One exception is School Library Journals "Touch and Go" blog, which posted its first e-book review in August 20II. ${ }^{34}$ Other outlets that review materials for young readers have gradually increased their content in this area, and some seem to have undertaken a retrospective reorganization of content in their online venues, collecting isolated reviews under an apps or e-books label once a number of these evaluations have accumulated. While efforts to conceptualize the essential properties of children's e-books are underway, most review sources maintain the existing broad divisions of age or grade level, genre (fiction or non-fiction), and medium (paperback or hardcover). ${ }^{35}$ The current practices of producers and reviewers, who generate the most readily observable activity in children's e-books, suggest that far from being a force that threatens or undermines print, the development of e-books for young readers is taking place on an uneven and varied playing field. Critical analysis and production alike have yet to coalesce.

The definition of children's literature is a subject of scholarly dialogue and it is another indicator of the alignment of print and electronic books for young readers. In the International Companion Encyclopedia of Children's Literature, Karin Lesnik-Oberstein writes, "Attempts to dismiss categorization and definition of texts as a side issue which should not be an end in itself are very problematic when it comes to children's literature: how do we know which books are best for children if we do not even know which books are 'children's

34 The "About" description of the blog does not provide its origination date; instead, it is derived from the earliest available post on the site, Daryl Grabarek, "Review: Fiske Interactive College Guide 20II for the iPad," 3 August 20II, http://blogs. slj.com/touchandgo/20II/o8/o3/review-fiske-interactive-college-guide-20II-forthe-ipad/.

35 The most recently created award for youth literature/media conferred under the auspices of the American Library Association is the Odyssey Award, initiated to recognize high-quality audiobooks for young people. Titles receiving the award between 2008 and 2012 have all been recordings of previously published, printed texts, rather than digital presentations of text and images that could allow the source matter to be considered an e-book. The Odyssey is clearly intended for recorded books, rather than as an entrée into the variously constructed children's e-book. For award criteria, citations, and honoured works, see Association for Library Service to Children, American Library Association, "Odyssey Award Eligibility and Criteria," accessed 9 July 20I3, http://www.ala. org/alsc/awardsgrants/bookmedia/odysseyaward/odysseyawardeligibilitycriteria/ odysseycriteria. 
books'?"36 In describing the challenges that accompany attempts to define "children's books," Lesnik-Oberstein evokes the historic belief that children's literature ought to have improving qualities. Her discussion of evaluation gives rise to the usual questions: the disparities of perspective that suggest childhood is either a natural state or a construct; the relative value of works that are didactic and those that amuse; and issues of emotion, sophistication, power, and morality on the page. Her conclusion, that children and children's literature are "enmeshed," is also taken up by other critics. ${ }^{37}$ Lerer notes that disagreements about what children's literature is and what it ought to be have existed for nearly as long as stories for children have. He calls attention to another differential: is children's literature that which is written specifically for the young reader or is it any work that a child might find engaging? ${ }^{38}$ He concludes that children's literature is "what children have heard and read" and "books that are taken into childhood, that foster social communication, and that, in their interaction with their readers, owners, sellers, and collectors, teach and please ... Their stories, poems, plays, or treatises may well have been composed with children in mind; or they may have been adapted for readers of different ages." ${ }^{39}$ A further issue, then, is the way in which the child reader is understood in the context of the children's e-book and whether the relationships among the interested parties change.

The literature on electronic books for children has also yet to consider fully the picture book, the literature's dominant format. Sometimes referred to by the compound picturebook to signal the importance of the image, the picture book combines illustration and narration. ${ }^{40}$ Typically telling a story in thirty-two pages, picture books require readers to interpret both images and words. Despite their brevity, they can represent staggering investments of time and research by authors, illustrators, and publishers. Although author-

${ }_{36}$ Karin Lesnik-Oberstein, "Defining Children's Literature and Childhood," in The International Companion Encyclopaedia of Children's Literature, ed. Peter Hunt (New York: Routledge, 1996), I7.

37 Lesnik-Oberstein, I8; Karen Sanchez-Eppler, Dependent States: The Child's Part in Nineteenth-Century American Culture (Chicago: University of Chicago Press, 2005).

38 Lerer, Children's Literature, 2.

39 Ibid.

$4^{0}$ See Martin Salisbury and Morag Styles, Children's Picturebooks: The Art of Visual Storytelling (London: Laurence King Publishers, 20I2). 
illustrator Mo Willems says that he hopes to create a bond with children through his simple, unsophisticated art, some of his peers, like Kadir Nelson, author-illustrator of We Are the Ship: The Story of Negro League Baseball and Heart and Soul: The Story of America and African Americans, have been known to spend seven years creating the panels for a single book. ${ }^{4 \mathrm{I}}$ The picture book, then, is a varied, complex endeavour whose production must be faithful to the artistic aims of skilled and talented illustrators. Salisbury has encapsulated the definition of the picture book: "It's a very special kind of book that tells its story primarily through pictures, with words, but neither makes sense without the other." ${ }^{2}$ Given that picture books depend on relationships between words and images, book design (as distinct from illustration) is important to the effect of a children's book. Douglas Martin has written that the aim of children's book design is to "[strike] a balance between the primacy of language and that of the pictorial image" and to "[mediate] between those who think and express themselves in words and those who think and create in a visual language." ${ }^{3}$ Typography, the placement of words relative to illustrations on the page, and the colour and size of the pages are just some of the physical aspects that are considered in the process of designing a children's book. Until fairly recently children's book designers were anonymous and unacknowledged in the publication process. Designer Molly Leach's work on the 1992 Caldecott Honor book The Stinky Cheese Man and Other Fairly Stupid Tales has been described by her illustrator-husband as "a watershed moment" in children's publishing that highlighted the transformational power of design. ${ }^{44}$ Leach is now routinely credited for her work. Diverse other books now exemplify the tendency to identify and

4I "Transcript from an interview with Mo Willems," Reading Rockets, accessed 3I May 20I3, http://www.readingrockets.org/books/interviews/willems/transcript/; "We Are the Ship: The Story of Negro Baseball," The Eric Carle Museum of Picture Book Art, accessed 28 May 2013, https://www.carlemuseum.org/nelson.

42 "The Artisty of Children's Picture Books Revealed," interview with Martin Salisbury by Renee Montagne, NPR Morning Edition, 23 April 2012, http://www. npr.org/20I2/04/23/I5IO53393/the-artistry-of-childrens-picturebooks-revealed.

43 Douglas Martin, "Children's Book Design," in International Companion Encyclopedia of Children's Literature (New York: Routledge, 1996), 463.

44 Lane Smith, “FAQ," Lane Smith Books, 20I2, www.lanesmithbooks.com. Leach's role in developing the book's distinctive visual content is acknowledged, though not by name, in a Horn Book review that labels the title "a masterpiece" in part because "its unconventional page arrangement and eclectic, frenetic mix of text and pictures, is a spoof on the art of book design." The brief review is available 
acknowledge children's book designers (e.g., Change Has Come: An Artist Celebrates Our American Spirit, which commemorated the 2008 election of Barack Obama; Drawing from Memory, the artistic memoir of Caldecott Medal winner Allen Say; and the short-filmturned-app-turned-picture-book, The Fantastic Flying Books of Mr. Morris Lessmore).

Regardless of content, children's book designers evaluate both text and reader in their efforts to arrive at a strategy for making the book readable and marketable. ${ }^{45}$ Multiple facets of reading, from where the book will be read to its sensory components, are important: "Picture books can and should involve as many of the senses as possible. Children smell paper and ink, and hear books as they snap, rustle, and squeak. And so all these matters have much to do with the reading experience." ${ }^{\prime 6}$ Galey confronts common contentions that the e-book is a featureless text and the "rhetoric of liberation" said to result from the ease of electronic access. ${ }^{47}$ While changing font or point size may have minimal effect on an unillustrated manuscript, differences in the way a page is displayed are far more significant in children's literature, particularly in picture books. As Martin explains, even the distance between the letters that make up a word affect a beginning reader's interpretive processes. Typography, especially for the young, serves as "an information tool." 4

What happens to all these core features associated with the children's book - the reader, the typography, the illustrations, the inherently changed sensory experience - when the medium is the pixel rather than the page? While there are some parallels in how print and e-books for children are discussed in the professional literature, there are also some notable differences. Ellen Wartella, Byron Reeves, and Nancy Jennings have traced the history of how experts evaluate new media and technologies for children, and the paradigm that they articulate resonates in the way e-books are discussed today. ${ }^{49}$ They

at Penguin.com (USA), accessed 29 May 2013, http://www.us.penguingroup. com/nf/Book/BookDisplay/o,,9780670844876, oo.html?sym= SYN\&\#awards.

45 Martin, "Book Design," 462-63.

46 Ibid., 467.

47 Galey, "Enkindling Reciter" 213, 216.

48 Martin, "Book Design," 464.

49 Ellen Wartella and Byron Reeves, "Historical Trends in Research on Children and the Media: 1900-1960," Journal of Communication 35 (Spring 1985): I18-33; Ellen Wartella and Nancy Jennings, "Children and Computers: Old Technology and New Concerns," Children and Computer Technology IO, no. 2 (2000), http:// 
argue that before scholars and industry leaders declare technologies safe, there are efforts to determine potential harm. Wartella and Jennings more recently observe a tendency to focus on technological devices like computers, followed by attention to content and effects. Concerns that e-books may be physically harmful are minimal, but the question of whether they benefit or impair a reader's progress or ability to learn is a strong theme in the professional literature. A further and more pronounced characteristic of writing about children's e-books is a tendency to focus on the technology instead of the idealized reader who appears in earlier discussions of children's literature.

Librarians and scholars have begun analyzing e-books in hopes of dismissing fears that they might not be optimal tools for teaching young readers. In 20II Lisa Guernsey investigated the use of e-books in preschools and elementary schools and her framing question echoed the fear of harm described by Wartella and Reeves: "Are electronic picture books good for kids, and can they get them hooked on reading by expanding access to engaging titles? Or are digital books one more step down that slippery slope to less and less interaction with print just when children need it most?" 50 Anxieties about e-books being "good," especially in their guise as purchases from the Apple App Store or another commercial vendor, recur again and again in the literature. ${ }^{5 \mathrm{I}}$ Proposed collection development criteria for use in children's libraries restate the concern about properties that could encourage children to forget that they are reading, advising the reader that such works would be unsuitable for library collections: "If a child can move around chirping birds, does that action serve the story? Even if it doesn't, does it actively distract a child from enjoying the story? Would a kid be inclined to just move around birds all day, entirely forgetting the story being told, or would they be inclined to continue reading or listening to it?" 52 For all the long-standing fears that a technological device like an e-book might harm a child, there are also those who think that it is the original books that suffer most from digital treatments. Desirable attributes of children's e-books, as in this suggested evaluative criterion, include fidelity to the stories that are being remade as e-books: "Adaptations of print books present faithful representations with all interactive elements enhancing - not

futureofchildren.org/publications/journals/article/index.xml?journalid=45\&arti cleid=20I\&sectionid=I308\&submit.

so Guernsey, “Are Ebooks Any Good?” 28.

5I Elizabeth Bird, "Planet App," School Library Journal 57, no.I (201I): 26-3I.

52 Ibid, 27. 
undermining - the original narratives." ${ }^{53}$ This concern aside, much contemporary discussion of the children's e-book includes harmbenefit analyses or is presented within a good-versus-evil context that idealizes or demonizes the e-book.

The child for whom the e-book is intended is rarely central to the discourse of electronic books. One 20Io review of the iPad argues that the device best serves students' needs because of its technological features, specifically the quality of screen displays and battery life. The iPad's presumed superiority to other devices as well as to print books is attributed to the idea that the reviewer's daughter "and her generation will be naturally bilingual when it comes to print and digital reading; what's exciting is that digital is almost guaranteed to be her primary language, thanks to devices like the new Apple iPad." 54 This notion of the digital native, likely derived from Marc Prensky's 200I essay "Digital Natives, Digital Immigrants," is unexplicated and simply declared a norm of twenty-first century culture. What defines this new generation of readers is the use of microcomputers since childhood, a behaviour that Prensky believes has "physically changed" young people's brains. Regardless of the veracity of those claims, Prensky correctly notes that digital technologies like "computer games, email, the Internet, cell phones and instant messaging are integral parts of their [young readers'] lives." 55 The belief that e-books are optimal for children, then, often elides technology use and brain functions associated with language. Guernsey likewise uses the label "Young Readers" to introduce a discussion of the technological attributes of various devices rather than to analyze young people's use of them. ${ }^{56}$ The same tendencies prevail in presentations by librarian Nicole Hennig, in which children's reading is briefly acknowledged. ${ }^{57}$ Despite

53 Katie Bircher, "What Makes a Good Picture Book App?" The Horn Book (March/ April 20I2): 78 .

54 Christopher Harris, “A Souped-up Picture Book," School Library Journal 56, no. 3 (March 20IO): I4.

55 Marc Prensky, "Digital Natives, Digital Immigrants," On the Horizon 9, no. 5 (200I), I, http://www.marcprensky.com/writing/prensky\%20-\%2odigital\%20 natives, \%2odigital\%2oimmigrants\%20-\%2opartI.pdf.

56 Guernsey, “Are Ebooks Any Good?" 28.

57 Nicole Hennig, "Reading on E-Book Devices, the User Experiences" (presented at the Handheld Librarian Online Conference, 29 July 20I0, http://www. hennigweb.com/presentations/); Nicole Hennig, "Introducing the Book as iPad App," ALA Tech Source Webinar, I March 2013. A summary is available at http://www.alatechsource.org/blog/2013/o2/introducing-the-book-as-ipadapp-free-webinar.html. 
occasional nods to the child, critics and practitioners like Hennig and Prensky believe that device is supreme, shaping both behaviour and biology.

Disparity of opinion about how to make sense of the children's e-book prevails, and there is much scrutiny of, as well as frequent reference to, the multi-media features of some of the mostly highly touted titles. One research team has developed subcategories of the children's e-book: enhanced e-books, with "bells and whistles like games, videos and interactive characters from the story embedded within a page," and basic e-books that are "print books put into a digital format with minimal features like highlighting text and audio narration. ${ }^{18}$ Guernsey is among those who argue that a certain percentage of non-textual elements makes the product something other than a book and more like a movie or a game. ${ }^{59}$ The ability of a digital version to maintain "all original page-turns and pacing" may be regarded as an essential attribute. ${ }^{60}$ Elsewhere, dyadic reading - an exchange between parent and child centred on a book - is essential: "A proper picture book app lets a parent and child read, listen to, or explore a book in a fun and interactive manner." ${ }^{\text {"6I }} \mathrm{A}$ list of eight evaluative criteria has been developed, articulating principles historically of interest to educators and librarians. It includes the standard picture-book criterion - "how well is the art integrated with the text?" - and a challenge: "What does the app provide that a simple lapsit with a print book and an adult does not?" ${ }^{2}$ From librarians' and researchers' efforts to grapple with this relatively new medium, it is also evident that many, if not all, definitions to date understand the children's e-book in relation to its print antecedent. Others contend that an e-book is simply a book, as in this characterization of industry developments, in which devices, magazines, books, and apps are effectively part of the same picture:

A year ago, Apple's iPad tablet arrived on the scene, turning digital glossy magazines and colorful digital books into a reality. The iTunes App Store is now brimming with vivid graphics

58 At present, an issue brief, rather than a full articulation of findings, is available: "E-book QuickStudy," Research \& Initiatives, Joan Ganz Cooney Center at Sesame Workshop, accessed 29 May 2013, http://joanganzcooneycenter.org/ Initiatives-40.html.

59 Guernsey, “Are Ebooks Any Good?" 30.

6о Bircher, "What Makes a Good Picture Book App?" 74.

6I Bird, "Planet App," 26.

62 Ibid., 27. 
and creative games for kids, including hundreds of book-like offerings, such as Green Eggs and Ham and Pat the Bunny. Not long after the emergence of the iPad, Barnes and Noble unveiled the NookColor - a \$250 device with a color touchscreen slightly smaller than the iPad's. It features Nook Kids, an online shop where you can purchase from a growing collection of classic and popular picture books. ${ }^{63}$

For all that this sort of comment attempts to erase the differences between electronic books and games, remarks from some producers suggest the children's e-book publishers could go further in rethinking the text; developers at ScrollMotion want to ensure that their children's products are "not just an electronic representation of the book." The company's statement of purpose announces that it is "reshaping how people experience digital information and entertainment" and "changing the way the world's biggest companies, from Oprah and Sesame Street to G.E. and Disney, publish and interact with content across children's books, magazines, textbooks." ${ }^{\prime 64}$ Collectively, these statements indicate a spectrum of digital material that could be labelled a children's e-book.

At present, the children's e-book is defined more by producers and devices than by a set of core properties or values. While children's librarians and those in the children's book trade may wish for an e-book that embraces and enhances the attributes of the printed book, commercial producers seek to change reading behaviours and promote media consumption. ${ }^{65}$ Attention to technological capabilities is a recurrent theme. Hennig promotes the iPad as a means of accessing the children's book, proclaiming, "It's beautiful what they're doing with children's books on this platform." ${ }^{66}$ To the extent that a children's book is defined, as Lerer and others would have it, by its use by young readers, what often characterizes a children's e-book is a reliance on previously printed children's material. There are also instances when the conventions of print books, whether textual or social, have been adopted. As one article explains, technological advances mean that "Now you can sit on the sofa with a five-year-old and experience a digital version of cozy co-reading, still basking in

\footnotetext{
Guernsey, “Are Ebooks Any Good?” 28.

64 Craig Morgan Teicher, "E-books Go Interactive," Publishers Weekly 256, no. 34 (2009): 23; "About Us," ScrollMotion, http://www.scrollmotion.com/aboutus. php.

65 Jenkins, Convergence Culture.

66 Hennig, "Reading on E-Book Devices."
} 
a book's beautiful illustrations and even hearing the pages turn." 67 The children's e-book in the twenty-first century may simply be whatever the dominant content providers are capable of producing, and whatever parents, instructors, and librarians are willing to buy.

\section{Purveyors of Children's E-books: Assessing Large Content Providers}

Despite energetic pronouncements about the future of the e-book and the possibilities such technology affords young people whose parents or school or public libraries can afford it, there are multiple indicators that e-books will not soon dominate the children's book market. In 20II, e-books accounted for only 5 percent of children's book sales, and predictions of higher figures in the future must be contextualized by the closure of Borders stores and the resulting reduction in bricks-and-mortar retail outlets. ${ }^{68}$ The long-term viability of digital storefronts is also far from guaranteed. Although the number of children's book apps is proliferating, some early entrants into the children's e-book market no longer exist, ${ }^{69}$ and a number of providers, like the University of Maryland's International Children's Digital Library, make children's e-books available at no charge. The ways in which individuals, librarians, and teachers acquire children's e-books, then, vary and include recourse to both the earliest online publishing endeavours like Project Gutenberg and contemporary commercial innovations like Apple's App Store.

The number of potential outlets where one may find children's e-books further differentiates digital content from printed children's materials. Whereas a children's room in a public library or a young readers section of any bookstore contains a vast number of items regardless of the publisher and the intricacies of printing technology used by the press, the same is not true of e-books. One public library director in California has described access to e-books as a "messed up situation - the copyright nightmares, the publishers, the fragmented formats, the ridiculous terms of service, the device incompatibility, the third-party aggregation companies libraries do

67 Guernsey, "Are Ebooks Any Good?" 30.

68 “Children's Books for Spring," Publishers Weekly 259, no. 8 (20I2): 19.

69 Walter Minkel, "Coming to a Small Screen Near You: Children's Elibrary is Marketing E-picture Books to Libraries," School Library Journal 48, no. 7 (2002): 2 . 
business with." ${ }^{70}$ Overdrive, the primary distributor of e-books to American public libraries, uses formatting that at times fails to display children's picture books as designed. Moreover, Overdrive's ability to aggregate titles is limited and does not provide anything near to the full range of children's e-books on the market. Some publishers like Penguin Group USA have refused to license their e-books for library circulation. At the same time, Penguin is the only one of the so-called Big Six publishers (Macmillan, Penguin, Random House, HarperCollins, Simon and Shuster, and Hachette) to create a children's e-book division, Apps for Young Readers. ${ }^{7 \mathrm{I}}$

Meanwhile, searching for available titles varies across device. While Barnes and Noble's NOOK Store has specific divisions for teens and children, further divided by age, none of the twenty-one categories used to organize content in the Apple App Store are specific to young readers. In fact, the nature of the indexing in the App Store means that it best serves someone conducting a known-item search. Producer and device determine the available texts. If one searches for children's e-books in the Apple App Store via an iPhone, for example, titles available as apps for the iPad will not display in the results. Items available from the NOOK Store may be accessed across devices by installing a device-specific NOOK app as well as the proprietary device. This holds some promise for improved display of picture books, as promotions for the NOOK Color boast of the high quality of images, even while aligning the reader with a particular for-profit company. Use of children's e-books, then, requires a would-be reader - or his or her parent or guardian - to be zealous, seeking content across platforms, or indiscriminate, taking whatever is readily available on the device at hand when it comes to selection of reading material.

The children's e-book market is currently made up of a handful of what could now be considered established producers and what might best be described as emerging digital micro-presses, some of which are not publishers in the traditional sense. Among the new companies that offer a limited number of titles, a few are particularly notable. Atomic Antelope, which produced Alice for the iPad to great fanfare in 20IO, promotes only three digital titles for children on its web site: Alice for

\footnotetext{
70 Sarah Houghton, "I'm Breaking up with eBooks," Librarian in Black (blog), I August 20I2, http://librarianinblack.net/librarianinblack/20I2/o8/ ebookssuckitude.html.

${ }^{71}$ “Apps for Young Readers," Penguin; Penguin Young Readers, accessed 29 May 2013, http://us.penguingroup.com/static/pages/youngreaders/teens/apps.html.
} 
the iPad, Alice in New York, and Nursery Rhymes. ${ }^{72}$ Its Alice books have received positive, even enthusiastic, reviews, including one claiming that Alice for the iPad "heralded a new era for the e-book."73 Disney's Digital Books outlet currently features thirty-four titles; distinctive among these offerings are Minnie Bow Maker, Learn Chinese: Toy Story 3 - Disney Language Learning, Disney Epic Mickey Digicomics, and Don't Let the Pigeon Run This App. ${ }^{74}$ These titles represent a range of content from games to language learning to revival of some of the original Disney cartoons to an animated version of Mo Willems's popular picture book, Don't Let the Pigeon Drive the Bus. While many Disney movies are based on fairy tales like Cinderella or children's stories like The Jungle Book, the majority of Disney e-books are more related to movie products through their graphic or visual content than to any originating texts. Open Road Integrated Media is another media company that has made the Boxcar Children series available as e-books, including graphic novel formats. ${ }^{75}$ The limitations of this product-specific focus are also evident in the company's description of its purpose - to create "connections between authors and their audiences by marketing its ebooks through a new proprietary online platform, which uses premium video content and social media." ${ }^{6}$ The company emphasizes words like marketing and proprietary, excluding mentions of reading or children. Nonetheless, these companies have produced e-books that have garnered a great deal of attention. The overall number of titles they offer is small and their mission seems different from the traditional interest of both children's publishers and youth services in libraries - namely, the interest in supplying young readers with strong, appealing works. This interest led to the increased availability of children's books in the United States. ${ }^{77}$

The tendency to rely on media corporations rather than traditional publishing houses to produce e-books has not gone unremarked, either by authors or producers. Rosemary Wells, author of Voyage

72 Atomic Antelope, http://www.atomicantelope.com/.

73 "Chris Stevens on Alice for the iPad, Book Apps, and Toronto: A Q \& A," Toronto Review of Books, 9 January 20I2, http://www.torontoreviewofbooks. com/20I2/oI/chris-stevens-on-alice/.

74 “Disney Digital Books," accessed 29 May 2013, http://www.disneybookapps.com.

75 "Gertrude C. Warner," Open Road Integrated Media, accessed 29 May 2013, http://www.openroadmedia.com/books/the-boxcar-children-super-summer.aspx.

76 Open Road Integrated Media, accessed 29 May 20I3, http://www.openroadmedia. com.

77 Jacalyn Eddy, Bookwomen: Creating an Empire in Children's Book Publishing (Madison: University of Wisconsin Press 2006). 
to the Bunny Planet, has declared herself "all for it (the e-book) and going to join in soon!"78 while Ursula LeGuin, author of the enduring Earthsea trilogy, envisions a dystopian future: "If ebooks largely replace printed books, and the public libraries are decimated or eliminated as a permanent resource open to everybody, we may be able to access books only through the corporations. It will not be easy to get a book the corporations have decided is unprofitable, outdated, unnecessary, or unpleasing; it may be very difficult to find out whether a text has been cut or tampered with; there may be no way to know that a book ever existed." ${ }^{\prime 79}$ Even a publisher like Chris Ware of Atomic Antelope has reservations about the quality of material produced under current development models. His concerns are worth quoting at length:

The major publishers have completely abdicated responsibility for producing the digital versions of their catalogues ... The big problem is that most publishers don't care about the iPad or eBooks very much, whether this is an aesthetic rejection based on the publisher's historical reverence for the printed page, or a reflection of the relatively small profits to be made on the iPad so far, it's hard to know. What's happening at the moment is that most publishers are handing their major titles over to app developers who are ruining these titles with rushed, unprofessional layout and design. There is this weird situation where programmers are suddenly being given free rein to design books. We watch as publishers like Random House outsource the design of cherished titles to programmers who - despite their excellence at programming - are not designers. The complete lack of care and attention paid to the production of digital books is genuinely mystifying. ${ }^{80}$

This "complete lack of care and attention" may be a product of the changes taking place in the publishing industry and as new producers enter the children's book market. In 2012 the National Broadcasting Company (NBC) announced plans to launch an e-book line and librarians immediately began to speculate if its content would be available to libraries. ${ }^{8 \mathrm{I}}$ For some time now, publishers of reference works

\footnotetext{
78 Roger Sutton, "Five Questions for Rosemary Wells," Notes from the Horn Book (October 20Io), http://archive.hbook.com/newsletter/archive/20Io/notes_octıo. html\#articler.

79 Ursula LeGuin, "Libraries and Ebooks," Book View Café (blog), Book View Café, 27 August 20I2, http://bookviewcafe.com/blog/20I2/o8/27/libraries-and-ebooks/.

80 "Chris Stevens on Alice for the iPad, Book Apps, and Toronto."

8I "NBC Launches EBook Division," Early Word, 24 January 20I2, http://www. earlyword.com/20I2/oI/24/ nbc-launches-ebook-division/.
} 
for children, including Encyclopedia Britannica and World Book, have offered enhanced, online versions of their encyclopedias and related publications. ${ }^{82}$ These works, whose electronic versions are described as databases rather than reference e-books because of the tendency to search for specific entries, were regularly used at least five years prior to the explosion of interest in the children's e-book. World Book features a distinctive component, offering young people the opportunity to ask questions that are answered by a roving editor who has sought out and video-recorded experts on the topics of interest. ${ }^{83}$ These kinds of online reference books are rarely purchased by individuals and instead are licensed by institutions including school and public libraries. Some e-book producers have positioned themselves to be visible and familiar to institutional purchasers of children's e-books. The Canadian TumbleBooks Library is a well-known provider of fiction and non-fiction. Its owner has long marketed its collection of e-books for children to librarians and has exhibited at major library conferences. In contrast to most other publishers and aggregators, TumbleBooks' pricing and usage models are intended to serve a broad number of users, in or outside the library. ${ }^{84}$

How, then, might the state of the market for children's e-books be understood? Despite Lerer's broad definition of children's literature, I have opted for a more restrictive way of thinking about children's e-books, considering only material with words that a child or his or her parent, guardian, or caregiver might read, even if there is accompanying audio. To rely on Lerer's concept of children's literature would include a vast assortment of media, including television and potentially even streaming video - media outside the scope of this essay. My criteria are more restrictive than those employed by some public libraries, such as the New York Public Library, which includes video of books being read aloud and story-teller performances in its online listings of e-books for children. ${ }^{5}$ Instead, my aim is to represent titles that might be included in a library catalogue, reflecting selection and acquisition by a children's librarian. Comparing only

\footnotetext{
82 Jennifer Burek Pierce, "World-Class Wonder," American Libraries, 38, no. 6 (2007), I28.

83 Jennifer Burek Pierce, "Encyclopaedic Focus," American Libraries, 39, no. Iо (2008): 60.

84 Jennifer Burek Pierce, "Booting up Book Lovers," American Libraries, 38, no. Io (2007): 6I.

85 Read Children's E-books Online, New York Public Library, http://kids.nypl. org/reading/Childrensebooks.cfm.
} 
those producers who have more than one hundred titles, rather than looking at individual titles, reveals a further dynamic (see Table I). It is apparent that recent materials under copyright are accessible only upon payment; free, unrestricted digital materials are primarily historical works. This means, given the limitations on library lending of e-books, that the vast majority of recent, popular digital works for young people must be purchased by individual consumers.

\section{Table I. Comparing Larger Children's E-Book Outlets}

\begin{tabular}{|l|c|c|c|c|c|c|c|}
\hline Publisher/ Provider & Date & $\begin{array}{c}\text { Works in } \\
\text { Copyright }\end{array}$ & $\begin{array}{c}\text { No. of } \\
\text { Items }\end{array}$ & $\begin{array}{c}\text { Device } \\
\text { Specific }\end{array}$ & $\begin{array}{l}\text { Multi-media } \\
\text { Features }\end{array}$ & Languages & $\$$ \\
\hline $\begin{array}{l}\text { Project Gutenberg: } \\
\text { Children's } \\
\text { Bookshelf }\end{array}$ & I971 & No & I00+ & No/C & $\begin{array}{l}\text { Limited } \\
\text { audio, images }\end{array}$ & English & Free \\
\hline Overdrive & 1986 & Yes & I00+ & Yes & $\begin{array}{l}\text { Limited } \\
\text { audio, images }\end{array}$ & $\begin{array}{l}\text { English; } \\
\text { others not } \\
\text { specified }\end{array}$ & $\$$ \\
\hline $\begin{array}{l}\text { Children's Books } \\
\text { Online: The } \\
\text { Rosetta Project }\end{array}$ & 1996 & No & I00+ & No/C & Images & $45^{89}$ & Free \\
\hline $\begin{array}{l}\text { TumbleBooks } \\
\text { Library }\end{array}$ & 2000 & Yes & 833 & No/C & $\begin{array}{l}\text { Audio, } \\
\text { video, games, } \\
\text { quizzes }\end{array}$ & 3 & $\$$ \\
\hline $\begin{array}{l}\text { University of } \\
\text { Maryland: } \\
\text { International } \\
\text { Children's Digital } \\
\text { Library }\end{array}$ & 2002 & No & 4643 & No & $\begin{array}{l}\text { Limited } \\
\text { images }\end{array}$ & $6 \mathrm{I}$ & Free \\
\hline
\end{tabular}

86 If the content provider or a reviewer does not specify the number of titles, and it is readily apparent that more than one hundred titles are part of the collection, then the designation Ioo+ is used in lieu of an actual count. For instance, Children's Books Online: The Rosetta Project, aims for continuous upload and prefers to offer descriptions of the number of pages available rather than the number of books.

87 "C" designates the need for an Internet connection to access titles.

88 Overdrive, "Children's, Young Adult \& International Titles Represent Fastest Growing Segments in Library \& School eBook Catalogs," news release, 8 August 20I2, http://www.overdrive.com/News/Childrens-Young-Adult--InternationalTitles-Represent-Fastest-Growing-Segments-in-Library--School-eBook-Catalogs.

89 "Children's Books Online: The Rosetta Project," accessed 3r May 2013, http:// www.childrensbooksonline.org/.

90 TumbleBooks has begun to offer a limited number of titles for direct download to devices. 
Not all children's publishers have developed e-book versions of their titles. Children's Book Press, founded in 1976 and now an imprint of Lee \& Low Books, was the first dedicated multicultural children's book publisher in the United States. It promoted distinctive cultural and ethnic narratives not made available by other presses and its titles are only available in print. ${ }^{9 \mathrm{I}}$ This is just one example of a press that has not made (and may never make) its titles available electronically.

Media theorists from Richard E. Rubin to Henry Jenkins have observed the prevalence of assumptions that new digital media would replace older formats..$^{92}$ They have also observed the myriad ways in which these predictions fail to materialize, focusing instead on relationships between old and new. Children's books represent a further instance of what has been called "convergence" or "intermediation," a phenomenon in which individuals use various print and electronic technologies together, rather than discarding the former. Among the narratives that exemplify the trend are J.K. Rowling's Harry Potter series and the fan fiction developed in response to it. ${ }^{93}$ While scholars like Jenkins and Striphas note that corporations like Warner Brothers, eager to protect their rights to the Harry Potter brand, sometimes contest particular pieces of fan fiction and other derivative works, no one in the publishing trade or in librarianship has given much consideration to the online child-authored text as an e-book. This implies an additional criterion at work in the shaping of the e-book for children; for all that fan fiction may be scrutinized by lawyers and studied by scholars, it is not represented as children's reading material. E-books for children, then, are titles produced by professional authors and released by authorized producers.

At present, trade publications significantly outnumber scholarly considerations of the children's e-book. As a result, the children's e-book is under-theorized and is defined by marketing and advertising rather than by analysis of content and accessibility. The dominance of television and other screen media in children's lives has been sustained longer than the dominant role of earlier technologies and

91 Wendy Werris, "Lee \& Low Acquires Children's Book Press," Publisher's Weekly, 26 January 20I2, http:/www.publishersweekly.com/pw/by-topic/childrens/ childrens-industry-news/article/50362-lee--low-acquires-children-s-book-press. html.

92 Jenkins, Convergence Culture 5, I4; Richard E. Rubin, Foundations of Library and Information Science (New York: Neal-Schuman Publishers, 20IO), I2.

93 Jenkins, Convergence Culture, I70. 
the potential impact may be more powerful as well. ${ }^{94}$ As the number of screen-based books for young readers proliferates, further scrutiny is needed to assess when an app is a book and when an app is just an app. Much critical commentary that attempts to draw this line is produced by librarians and book reviewers. To date, material published often echoes the concerns of those who established the fields of children's literature and library services for the young. These early leaders publically decried series fiction for its lack of literary merit, often while quietly putting it on their libraries' shelves, and in the twenty-first century, those who follow in their footsteps decry the app..$^{95}$ To evaluate their concerns, we must wait for studies that will record and assess what young readers - and most often, their guardians - do as they read e-books. ${ }^{96}$ In the end, then, there is something fundamental about children's e-books that we must know: what is children's literature?

\section{SOMMAIRE}

La littérature d'enfance et de jeunesse, longtemps caractérisée par des livres illustrés en couleurs, est loin d'imiter ce qui se fait comme publications pour un lectorat plus âgé. Même si les livres électroniques ont pris rapidement de l'importance durant les dernières années, la diffusion en mode numérique de livres pour enfants représente une faible part de marché, soit à peine cinq pour cent des ventes en 2011. Cet article passe en revue les recherches interdisciplinaires et les travaux d'érudition sur les livres électroniques pour enfants. Bien que perçu comme très relatif, le fait de reconnaître le livre électronique pour enfants en tant qu'entité multimédia est essentiel pour la

94 Wartella and Robb, "Historical and Recurring Media Concerns."

95 Jennifer Burek Pierce, "No More Optical Delusions: Science in the Works of Oliver Optic" (paper presented at the annual meeting of the Society for the History of Authorship, Reading, and Publishing. Washington, D.C., I7 July 2OII).

96 Lotta C. Larson, "E-Reading and E-Responding: New Tools for the Next Generation of Readers," Journal of Adolescent \& Adult Literacy 53, no. 3 (2009): 255-58; Sally Maynard, "The Impact of E-Books on Young Children's Reading Habits," Publishing Research Quarterly 26, no. 4 (2010): 236-48; Ofra Korat, Adina Shamir, and Livnat Arbiv, "E-Books as Support for Emergent Writing with and without Adult Assistance," Education \& Information Technologies 16, no. 3 (2OII): 3OI-I8. 
raison que ce secteur de l'édition se présente lui-même comme un phénomène ambigu en s'alignant sur une catégorie de documents numériques appelés livres électroniques pour enfants. De plus, les comptes rendus de ce type de publications s'articulent notamment autour de la technologie au détriment du lecteur. Ces observations ne tiennent pas compte cependant des points de vues adoptés par les médias qui rejettent la croyance que le numérique devrait remplacer les anciens supports. Les livres pour enfants représentent un dossier primordial qu'on est convenu d'appeler "convergence» ou "intermédiation», un principe qui veut que les technologies de l'imprimé et de l'électronique doivent coexister au lieu de se voir supplanter les unes par les autres. Le livre électronique pour enfants suscite actuellement une attention des plus soutenues de la part des services de mise en marché alors qu'elle devrait également faire l'objet de discussions sur son contenu et son accessibilité. 